\title{
Determination of biogas production potential from animal manure and GHG emission abatement in Turkey
}

\author{
Cengiz Karaca \\ (Mustafa Kemal University, Faculty of Agriculture, Department of Biosystems Engineering, Hatay 31040, Turkey)
}

\begin{abstract}
This study was aimed to determine biogas amount and the energy value which could be made from animal manure in Turkey. For this purpose, biogas potential was calculated with the number of dairy cattle and laying hens taking into consideration, which have high availability manure. Turkey has a total of about 8.9 million dairy cattle and 98 million laying hens. Annual total 92.1 million tons of manure is obtained from these animals. There are 89.2 million tons of cattle manure and 2.9 million tons of laying hens manure. Annual 1.6 billion $\mathrm{m}^{3}$ of biogas can be produced from the usable amount of this manure. The heating value of biogas produced from this manure is about 36.7 PJ. These values can provide $1.1 \%$ of Turkey's annual energy consumption ( $80.5 \mathrm{Mtoe})$. The distribution of these calculated data by province was mapped using a GIS Software's mapping option. When provinces are ranked according to the amount of biogas production, the top 10 are Konya, Erzurum, İzmir, Balıkesir, Kars, Afyon, Diyarbakır, Aydın, Ankara and Ağrı. Furthermore, the greenhouse gas (GHG) emission abatement was calculated for demonstrating the environmental benefits of the biogas production from animal manure. It was determined that the $\mathrm{CO}_{2}$ emission abatement annually ranging between 17.2-25.3 million tons could be provided with the evaluation of biogas potential which was calculated.
\end{abstract}

Keywords: biogas, biogas production potential, animal manure, GHG emission, Turkey

DOI: $10.25165 / j$.jjabe. 20181103.3445

Citation: Karaca C. Determination of biogas production potential from animal manure and GHG emission abatement in Turkey. Int J Agric \& Biol Eng, 2018; 11(3): 205-210.

\section{Introduction}

Energy plays a significant role in the future of the world. Energy is the center of economic improvement, and there is an obvious relation between energy consumption and living standards. Energy resources are divided into three categories: fossil fuels, renewable resources and nuclear resources ${ }^{[1]}$. The current global energy supply depends on fossil fuels (petroleum, lignite, coal and natural gas). The World's economies grow due to petroleum. Fossil fuels are restricted sources, gathered in a few bounded areas of the world. This case creates a dependency which is constantly insecure for countries that import energy from these regions.

Energy systems based on national biomass resources such as biogas will increase national energy supply security by reducing dependence on imported fuels. Unlike fossil fuels, biogas from anaerobic digestion is permanently renewable, as it is produced on biomass, which is actually a living storage of solar energy through photosynthesis. Biogas can enhance the energy stability of a country and provide a significant contribution to the protection of the environment and natural sources ${ }^{[2]}$.

Anaerobic digestion is a simple technology that allows for decentralized energy production from various biomasses, such as animal manure, energy crops and food industry wastes. Furthermore, anaerobic digestion has a few other environmental benefits like reducing the greenhouse gas. Biogas production from anaerobic digestion is determined as one of the most

\section{Received date: 2017-04-23 Accepted date: 2018-03-08}

Biographies: Cengiz Karaca, PhD, Assistant Professor, research interest: biomass energy, agricultural wastes, briquetting and pelleting techniques of wastes. Department of Biosystems Engineering, University of Mustafa Kemal, Hatay 31040, Turkey, Tel: +90-3262455845/1007, Fax: +90-3262455832; Email: cengiz.karaca@gmail.com. cost-effective methods for greenhouse gas abatement by recent studies $^{[3]}$.

Anaerobic digestion process is complicated with a number of consecutive and parallel biochemical conversions which are realized by different type bacterium in an oxygen-free environment. Biogas consists of $50 \%-70 \%$ methane $\left(\mathrm{CH}_{4}\right)$, and $30 \%-40 \%$ carbon dioxide $\left(\mathrm{CO}_{2}\right)$ with other gases in minor quantities ${ }^{[4]}$. Other components of biogas are water $\left(\mathrm{H}_{2} \mathrm{O}\right)$, oxygen $\left(\mathrm{O}_{2}\right)$, sulphur $\left(\mathrm{S}_{2}\right)$ and hydrogen sulphide $\left(\mathrm{H}_{2} \mathrm{~S}\right)$.

Biogas usage is understood as distinct from national and individual perspective. The states desire native energy to reduce the dependency of foreign energy. The main reasons for biogas production are an economic benefit from energy production, and management and treatment of agriculture and food processing residues. Assessment of renewable energy potential assists to focus the government policies and available technology on renewable energy sources. On the other hand, the theoretical potential of raw materials for biogas production could guide for individuals and for the most value added from the raw material available $^{[5]}$. Biogas from animal manure can help solve energy problems in rural areas and reduce the dependence on fossil fuels in urban areas. Furthermore, biogas can enhance regional economic improvement and the ecological environment with the greenhouse gas emission abatement from use of fossil fuel.

Because of increased energy demand and limited native energy resources, Turkey is energy-import country especially in oil and natural gas. Now about $25 \%$ of the total energy demand is being supplied by native sources. The primary energy demand of Turkey is supplied by natural gas $(35 \%)$, coal $(28.5 \%)$, petroleum $(27 \%)$, hydro energy $(7 \%)$, and other renewables $(2.5 \%)$. The total electric energy demand was $264 \mathrm{TW} \cdot \mathrm{h}$ in 2015 and it is growing quickly. The total electricity demand of Turkey is 
estimated at about $416 \mathrm{TW} \cdot \mathrm{h}$ in 2023 by the Ministry of Energy and Natural Resources. The distribution of other energy resources used in electricity production in 2015 was coal (28.4\%), hydro energy $(25.8 \%)$, wind energy $(4.4 \%)$, geothermal energy $(1.3 \%)$, fuel oil, diesel and naphtha $(1.6 \%)$, and biomass energy $(0.6 \%)^{[6]}$.

The main objective of this study was to determine the production potential of biogas from animal manure (only dairy cattle and laying hens) and draw attention to the GHG emission reduction from the substitution of fossil fuels with the estimated biogas potential. Also, these calculated data (biogas potential, its energy values of animal manure, and $\mathrm{CO}_{2}$ equivalent emission from animal manure) were mapped by a geographical information system (GIS) program. The maps were created to see more clearly the difference of the data from the provinces. A database was created within a GIS Software for Turkey and its provinces. The number of animals, calculated biogas potential, and its heating value and $\mathrm{CO}_{2}$ equivalent emission from animal manure in Turkey for 2015 year were entered into this database.

\section{Materials and methods}

Turkey is a country with a large agricultural sector between Asia and Europe. Turkey is one of a few self-contained countries in the world in terms of the basic agricultural products. Turkey has a large capacity to cultivate many species of crops and animals owing to its land and climate ${ }^{[7]}$. In Turkey livestock sector has a considerable potential and is an important part of agricultural sector and economy. Livestock constitute approximately $25 \%$ of the value of all agricultural production and contribute to the economic development of rural households. Seventy percent of the rural farms in Turkey own livestock. Most of these livestock farmers rely on their livestock for income by selling milk and animals as well as fertilizer for crops.

Within the scope of this study, Turkish Statistical Institute's 2015 animal statistic data has been used as material ${ }^{[8]}$. The data used in the calculation of the biogas production potential was related only with dairy cattle and laying hens population. Because the attainability of animal manures, as determined by staying time in the barn, is the highest value in a dairy cattle farm $(65 \%)$ and laying hens farm $(99 \%)^{[9]}$. Another animal data is not used in calculating of biogas amount for this ratio is lower.

\subsection{Calculation methods of animal manure and biogas production}

The following equations were used to calculate the amount of animal manure and biogas production ${ }^{[10,11]}$.

$$
A F M=\frac{N A \cdot M P P A}{1000}
$$

where, $A F M$ is the daily amount of fresh manure, $\mathrm{t} / \mathrm{d} ; N A$ is the number of animals; $M P P A$ is daily manure production per animal, $\mathrm{kg} /($ animal $\cdot \mathrm{d}) . \quad M P P A$ is 27.24 for dairy cattle and 0.08 for laying hens.

$$
A S M=A F M \cdot S M R
$$

where, $A S M$ is the amount of solid manure daily, $\mathrm{t} / \mathrm{d} ; S M R$ is solid manure ratio, $\%$.

$$
\text { TUSM }=A S M \cdot A O M \cdot 365
$$

where, TUSM is annual total usable solid manure, t/a; $A O M$ is attainability of manure, $\%$.

$$
A B=T U S M \cdot B C V_{S M}
$$

where, $A B$ is the amount of biogas, $\mathrm{m}^{3} / \mathrm{a} ; B C V_{S M}$ is biogas conversion value per mass unit of solid manure, $200 \mathrm{~m}^{3} / \mathrm{t}$.

$$
T H V=A B \cdot H V
$$

where, $T H V$ is the total heating value, $\mathrm{MJ} / \mathrm{a} ; H V$ is the heating value of unit biogas, $22.7 \mathrm{MJ} / \mathrm{m}^{3}$.

Electricity production from biogas with the gas engine was calculated by the following equation:

$$
E P=\frac{T H V}{3.6} \cdot E P E_{\text {Net }}
$$

where, $E P$ is electricity production, $\mathrm{MW} \cdot \mathrm{h} / \mathrm{a} ; E P E_{N e t}$ is the net electricity production efficiency of biogas engine $(40 \%)^{[12]}$.

For each province, the calculated values of the total amount, total biogas production, and total energy potential of these animal manures were mapped using a GIS Software.

\subsection{Calculation methods of GHG emission abatement from biogas system}

GHG emission lessening effect of biogas production is based upon two factors, emission reduction by manure management (ERMM) and emission reduction by energy substitution (ERES).

\subsubsection{ERMM}

Animal manure is handled as liquid slurry storage and open pond. Under anaerobic conditions (in the absence of oxygen) the extrication of animal manure produces $\mathrm{CH}_{4}$ throughout storage. The amount of methane production is affected by the storage time and the temperature of slurry. When manure is deposited as a solid with heap on grasslands, it is deposed to decay under more aerobic conditions and less methane is propagated. This $\mathrm{CH}_{4}$, produced from the exposed manure uncontrollably spreads into atmosphere. The most important benefit of a biogas system is preventing the uncontrolled methane emissions. The following methods were used to calculate the $\mathrm{CH}_{4}$ production from uncovered lagoon manure storage systems ${ }^{[13,14]}$. This calculation was done according to annual average temperature for each province.

$$
\mathrm{CH}_{4 \text { Manure }}=\mathrm{EF}_{(T)} \cdot \mathrm{N}_{(T)}
$$

where, $\mathrm{CH}_{4 \text { Manure }}=$ methane emissions from manure management, $\mathrm{kg} \mathrm{CH}_{4} / \mathrm{a} ; E F_{(T)}=$ emission factor for the described livestock category, $\mathrm{kg} \mathrm{CH} / \mathrm{animal} \cdot \mathrm{a} ; N_{(T)}=$ the number of animal of livestock species/category; $T=$ species/category.

$$
E F_{(T)}=\left(V S_{(T)} \cdot 365\right) \cdot\left(B_{o(T)} \cdot 0.67\right) \cdot\left(\frac{M C F_{S k}}{100}\right)
$$

where, $V S_{(T)}=$ volatile solid for livestock category per day, kg dry matter/animal.d; $B_{o(T)}=$ maximum methane production capacity, $\mathrm{m}^{3} / \mathrm{kg} ; 0.67=$ conversion multiplier from $\mathrm{m}^{3} \mathrm{CH}_{4}$ to $\mathrm{kg} \mathrm{CH}_{4}$; $M C F_{S, k}=$ methane conversion parameters for manure management system $(S)$, by climate region $(k), \%$.

$$
\text { ERMM }_{\mathrm{CO}_{2}}=\mathrm{CH}_{4 \text { Manure }} \cdot 25
$$

where, $E R M M_{\mathrm{CO}_{2}}=\mathrm{CO}_{2}$ emission reduction from manure management, $\mathrm{kg} \mathrm{CO}_{2} / \mathrm{a} ; 25=$ Coefficient of the $\mathrm{CO}_{2}$ equivalent of $\mathrm{CH}_{4}$ (The Global Warming Potential (GWP) of $\mathrm{CH}_{4}$ in $\mathrm{CO}_{2}$ equivalent over a 100 years' time-horizon).

\subsubsection{ERES}

In rural regions biogas can be used instead of solid fossil fuels and other biomass resources, because of high heat value (22.7 $\mathrm{MJ} / \mathrm{m}^{3}$ ). Therefore, the effect of $\mathrm{CO}_{2}$ emission reduction of biogas system depends on the amount of fossil fuel replacement. The ERES is computed as GHG emissions produced by biogas-substituted fuel consumption. This calculation is done separately for each province. This factor mightily bounds up with the kinds of fuels consumed in the reference system. In this part, 
$\mathrm{CO}_{2}$ emission reduction was calculated separately for each fossil fuel, which substituted the estimated biogas potential. The following equations were used for this ${ }^{[14]}$.

$$
E R E S_{\mathrm{CO}_{2} \text { fuel }}=F S \cdot C E_{\text {fuel }} \cdot E F_{\mathrm{CO}_{2} \text { fuel }}
$$

where, $E R E S_{\mathrm{CO}_{2} \text { fuel }}=\mathrm{CO}_{2}$ emission reduction for substituted fuel, $\mathrm{kg} / \mathrm{a} ; F S=$ Fuel substitution value of biogas energy equivalent, $\mathrm{GJ} / \mathrm{a} ; C E_{\text {fuel }}=$ Combustion efficiency of fuels; $E F_{\mathrm{CO}_{2} \text { fuel }}=\mathrm{CO}_{2}$ emission factors, $\mathrm{kg} / \mathrm{GJ}$.

$$
F S=T H V \cdot 0.6
$$

where, $T H V=$ Total heating value of biogas potential, GJ/a; $0.6=$ Combustion efficiency of biogas.

\section{Results and discussion}

\subsection{Potential of animal manure, biogas production and energy} value

Total animal manure potential of Turkey in the years of 2015 as a solid matter depending on the number of dairy cattle and laying hens is presented in Table 1.

Table 1 Number of animals, and total amount of animal manure as fresh and solid matter

\begin{tabular}{ccccccc}
\hline Animal & NA & $\begin{array}{c}\text { AFM } \\
/ \mathrm{t} \cdot \mathrm{d}^{-1}\end{array}$ & $\begin{array}{c}\text { SMR } \\
/ \%\end{array}$ & $\begin{array}{c}\text { ASM } \\
/ \mathrm{t} \cdot \mathrm{d}^{-1}\end{array}$ & $\begin{array}{c}\text { AOM } \\
/ \%\end{array}$ & $\begin{array}{c}\text { TUSM } \\
/ \mathrm{t} \cdot \mathrm{a}^{-1}\end{array}$ \\
\hline Dairy cattle & 8892536 & 89255138 & 12.7 & 11335402 & 65 & 7368012 \\
Laying hens & 97988312 & 2884722 & 25 & 721180 & 99 & 713969 \\
Total & & 92139860 & & 12056583 & & 8081980 \\
\hline
\end{tabular}

According to Table 1, the total amount of usable solid manure obtained from dairy cattle and laying hens is 8 million tons in the years of 2015 . Its distribution by the source is dairy cattle $(91.2 \%)$ and laying hens $(8.8 \%)$.

The quantity of biogas which can be obtained from the total animal manure as a solid matter along with the electricity production from this biogas is given in Table 2 .

According to Table 2, total biogas potential of Turkey was calculated to be $1.616 \mathrm{Mm}^{3} / \mathrm{a}$. Besides its heating value was calculated to be $36.7 \mathrm{PJ} / \mathrm{a}$. It was determined that $4.08 \mathrm{TW} \cdot \mathrm{h} / \mathrm{a}$ energy can be obtained by the conversion of all the biogas potential from animal manure into electric energy by means of a gas engine.

Table 2 Biogas potential and energy potential of biogas in Turkey

\begin{tabular}{ccccc}
\hline Animal & TUSM $/ \mathrm{t} \cdot \mathrm{a}^{-1}$ & $\mathrm{AB} / \mathrm{m}^{3} \cdot \mathrm{a}^{-1}$ & $\mathrm{THV} / \mathrm{GJ} \cdot \mathrm{a}^{-1}$ & $\mathrm{EP} / \mathrm{MW} \cdot \mathrm{h}_{\mathrm{el}} \cdot \mathrm{a}^{-1}$ \\
\hline Dairy cattle & 7368012 & 1473602325 & 33450773 & 3716753 \\
Laying hens & 713969 & 142793726 & 3241418 & 360158 \\
Total & 8081980 & 1616396050 & 36692190 & 4076910
\end{tabular}

A study carried out by Avcioğlu Onurbaş and Türker ${ }^{[15]}$ showed that the biogas energy potential of Turkey was found to be 2.18 billion $\mathrm{m}^{3}$ (49 PJ) in 2009.

When biogas potentials of some other countries are examined, it is seen that Turkey has a good potential. The biogas energy potential from animal manure in Denmark was estimated to be around $26 \mathrm{PJ}^{[16]}$. The potential of Germany for agricultural biogas production was estimated 20.6 billion $\mathrm{m}^{3}$. In Sweden the biogas energy potential from animal manure was estimated 153.4 PJ $\left(7.04\right.$ billion $\left.\mathrm{m}^{3}\right)$. The value of 6.4 billion $\mathrm{m}^{3}$ of the potential for biogas production in Poland was determined ${ }^{[17]}$. The biogas potential from cattle, pig manure, and small breedings is of about 1.9 billion $\mathrm{m}^{3}$ in Italy ${ }^{[18]}$. India has a potential of generating 63.8 billion $\mathrm{m}^{3}$ of biogas annually from 980 million tons of cattle manure ${ }^{[19]}$.

The top 10 provinces are aligned according to the biogas potential in Table 3.

\begin{tabular}{|c|c|c|c|c|c|}
\hline Province & Fresh manure $/ \mathrm{t} \cdot \mathrm{a}^{-1}$ & Biogas potential $/ \mathrm{m}^{3} \cdot \mathrm{a}^{-1}$ & Heating value/GJ $\cdot \mathrm{a}^{-1}$ & Electric energy $/ \mathrm{MW} \cdot \mathrm{h}_{\mathrm{el}} \cdot \mathrm{a}^{-1}$ & Share in total $/ \%$ \\
\hline Konya & 4762127 & 89755888 & 2037459 & 226384 & 5.55 \\
\hline İzmir & 3891539 & 69688794 & 1581936 & 175771 & 4.31 \\
\hline Erzurum & 4019414 & 66556630 & 1510836 & 167871 & 4.12 \\
\hline Balıkesir & 3393301 & 62401529 & 1416515 & 157391 & 3.86 \\
\hline Afyon & 2546217 & 59829000 & 1358118 & 150902 & 3.70 \\
\hline Kars & 3075941 & 51014974 & 1158040 & 128671 & 3.16 \\
\hline Diyarbakır & 2297568 & 38412784 & 871970 & 96886 & 2.38 \\
\hline Aydin & 2067983 & 34750901 & 788845 & 87649 & 2.15 \\
\hline Ankara & 1819548 & 34404299 & 780978 & 86775 & 2.13 \\
\hline Ağr & 2072447 & 34338825 & 779491 & 86610 & 2.12 \\
\hline Total & 45197341 & 377831399 & 12284187 & 1364910 & 33.48 \\
\hline
\end{tabular}

Table 3 Top 10 provinces with the highest biogas in Turkey

One-third of the total biogas potential in Turkey comes from 10 provinces, as shown in Table 3. Konya has the highest potential with almost $90 \mathrm{Mm}^{3} / \mathrm{a}$ and $5.55 \%$ of share in total. This is followed by İzmir $\left(69.70 \mathrm{Mm}^{3} / \mathrm{a}\right.$ and $\left.4.31 \%\right)$, Erzurum (66.55 $\mathrm{Mm}^{3} / \mathrm{a}$ and $4.12 \%$ ), Balikesir $\left(62.40 \mathrm{Mm}^{3} / \mathrm{a}\right.$ and $3.86 \%$ ), and Afyon (59.83 $\mathrm{Mm}^{3} / \mathrm{a}$ and $3.70 \%$ ) province.

The amount of biogas and their energy values were calculated separately for each province and were mapped using a GIS Software. The distribution map of biogas potential and its energy values per 81 provinces of Turkey are given in Figures 1 and 2 .

It is seen that biogas production potential from animal manure in Turkey is examined in 5 groups. The majority of the provinces of Turkey (53 province or $65.4 \%$ ) has biogas production potential between $1-20 \mathrm{Mm}^{3}$. There are 22 provinces $(27.2 \%)$ having the biogas production potential between $20.1-40 \mathrm{Mm}^{3}$. In other words, the annual biogas production potential of $92.6 \%$ of Turkey's provinces is below $40 \mathrm{Mm}^{3}$. Erzurum and Kars provinces in eastern Turkey, Konya and Afyon provinces in the middle, and İzmir and Balıkesir provinces in the western are seen as provinces which have the largest biogas production potential.

As of now, there are 19 plants which can produce biogas and electricity from animal manure in Turkey (Table 4). 


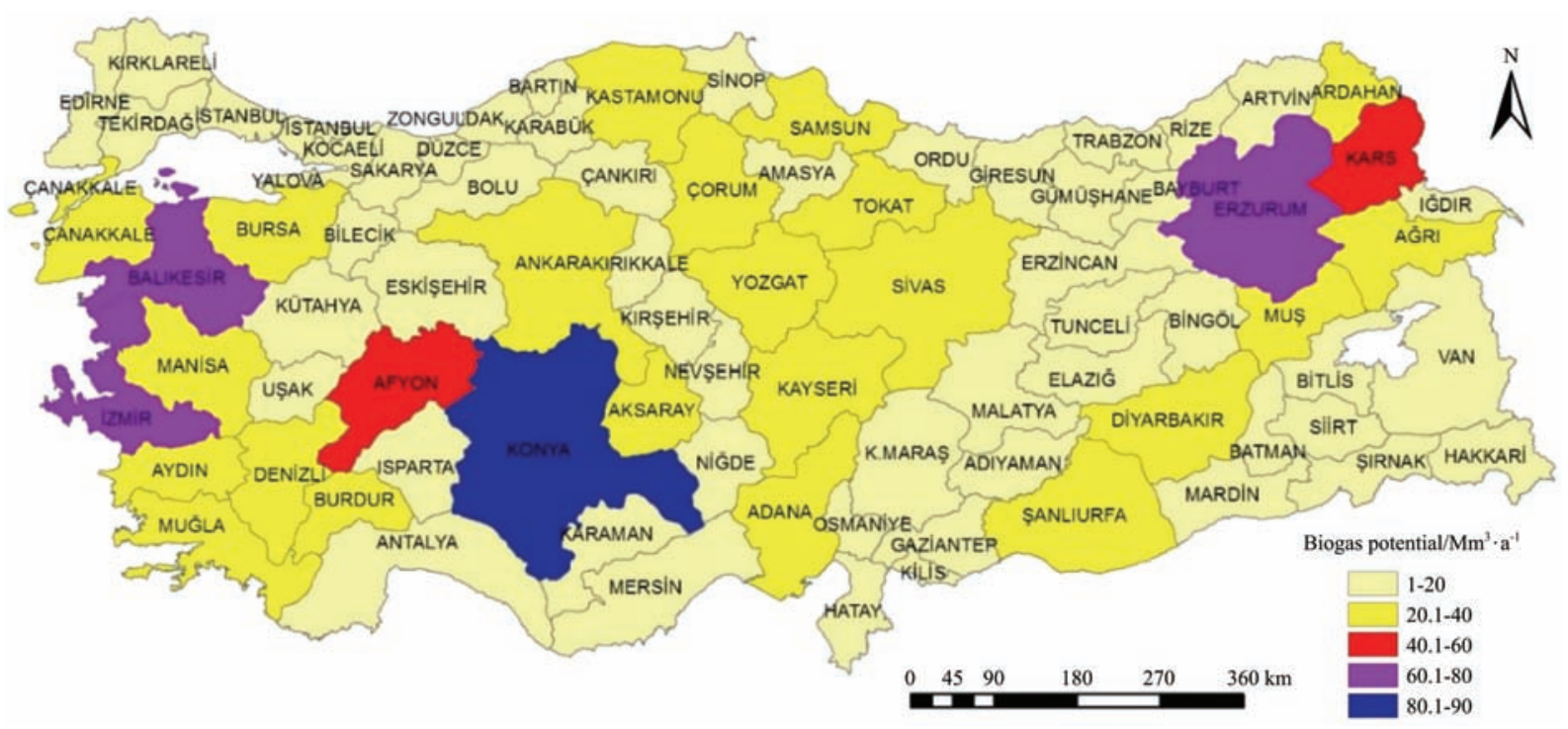

Figure 1 The map of biogas potential in Turkey

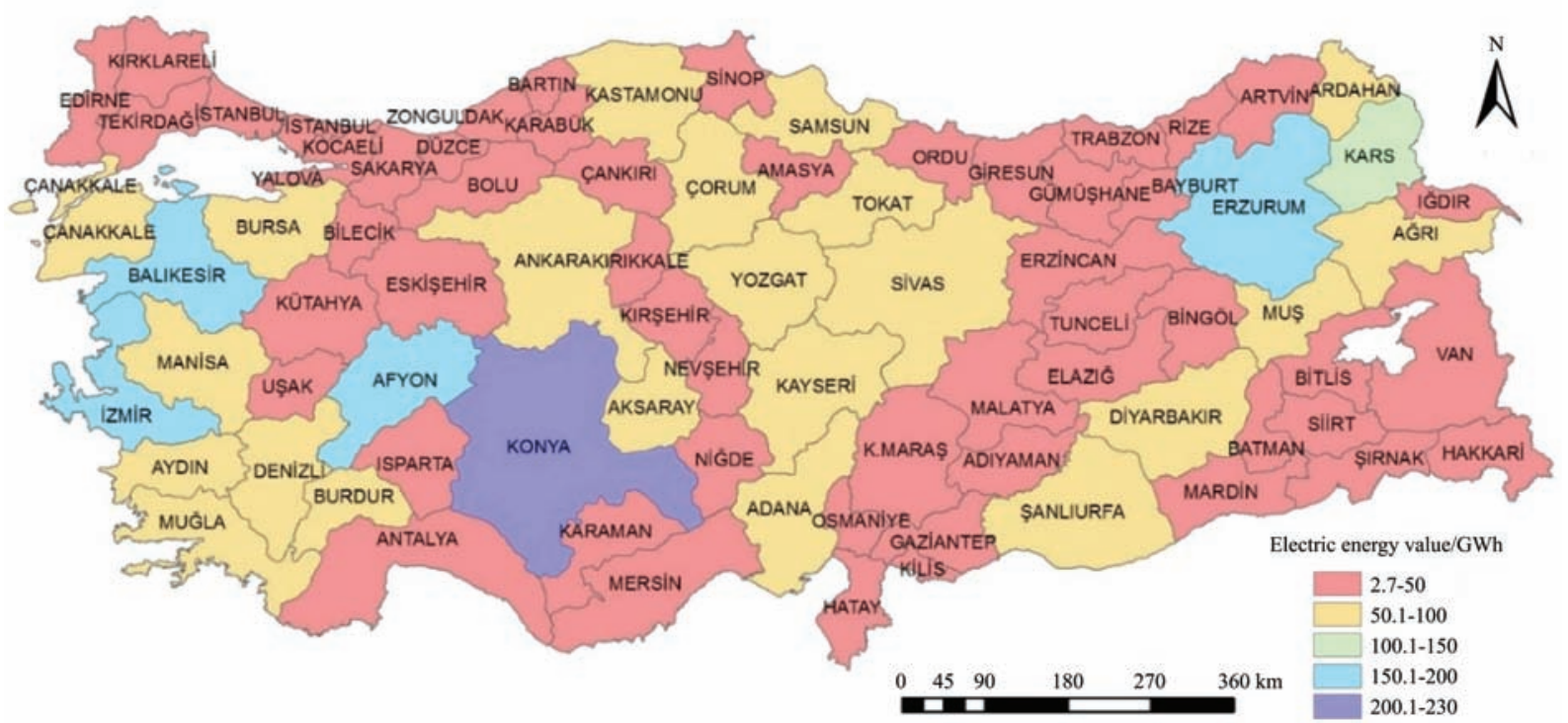

Figure 2 The map of electricity production from biogas in Turkey

Table 4 Biogas power plants sourced from animal manure in Turkey, as of the year 2016

\begin{tabular}{llc}
\hline Province & Name of biogas power plant & Installed power/MWel \\
\hline Aksaray & Aksaray OSB Biyogaz Tesisi & 6.40 \\
Kırklareli & Ovacık Biyogaz Enerji Santrali & 4.96 \\
Afyon & Afyon Biyogaz Santrali & 4.25 \\
Balıkesir & Gönen Biyogaz & 3.72 \\
Ankara & Beypazarı Biyogaz Tesisi & 2.48 \\
Aydın & Senkron Efeler Biyogaz Santrali & 2.48 \\
Afyon & Arel Enerji Biyokütle Tesisi & 2.40 \\
Bursa & Karacabey 2 Biyogaz Tesisi & 2.19 \\
Balıkesir & Edincik BES & 2.19 \\
Amasya & Sigma Suluova Biyogaz Tesisi & 2.04 \\
Ankara & Albe Biyogaz Santrali & 1.87 \\
Ankara & Polatlı BES & 1.55 \\
Sakarya & Karma Gıda Biyogaz Santrali & 1.49 \\
Sakarya & Pamukova Biyogaz Santralı & 1.45 \\
Karaman & Karaman Biyogaz Tesisi & 1.41 \\
Konya & Ekim Grup Biyogaz Tesisi & 1.24 \\
Antalya & Sezer Bio Enerji Biyogaz Tesisi & 0.62 \\
Kocaeli & İzaydaş Biyogaz Enerji Üretim Tesisi & 0.34 \\
Bursa & Karacabey Çiftlik & 0.33 \\
\hline & $\quad$ Total & 43.41 \\
\hline & & \\
\hline
\end{tabular}

When the calculated electric power production potential of province compared with the installed power of biogas power plant in this province, the compensating percentage of installed power of the calculated potential is highest in Kirklareli (93\%) and Aksaray $(82 \%)$. This percentage was determined in Ankara (51\%), Sakarya (47\%), Karaman (46\%), Amasya (34\%), Afyon (33\%), Bursa (28\%), Balıkesir (28\%), Aydin (21\%), Antalya (12\%), Kocaeli (9\%) and Konya (4\%) respectively. It is remarkable that, evaluation of very little potential in Konya where has Turkey's largest biogas potential, and a plant could not be established in Erzurum İzmir and Kars provinces. These power plants which are running now can use only $8 \%$ of the electricity generation potential from biogas in Turkey.

\subsection{GHG emission abatement from biogas system}

The result of this computation is called ERMM, which are shown in Table 5. The map of $\mathrm{CO}_{2}$ equivalent of emitted $\mathrm{CH}_{4}$ into the atmosphere from animal manure to be stored in the uncovered field is given in Figure 3.

The equivalent $\mathrm{CO}_{2}$ emissions resulting from animal manure are the highest level in the provinces of Konya, Erzurum and İzmir. The result of this computation can be observed as GHG emission reduction substituted by biogas, which is offered as ERES $_{\mathrm{CO} 2}$ fuel (Table 6). Total $\mathrm{CO}_{2}$ emission abatement from manure biogas 
system is given in Table 7.

Turkey's total greenhouse gas emissions in 2014, is determined as $467.6 \mathrm{Mt} \mathrm{CO}_{2}$ equivalent. The $10.6 \%$ of this $\mathrm{GHG}$ emission $(49.5 \mathrm{Mt})$ is based on agricultural activities ${ }^{[20]}$. This GHG emission can be reduced to $15 \mathrm{Mt}$ (about $30 \%$ ) by manure management with biogas systems. In addition, when fuel substitution is added, the total emission reduction can vary from 17.2 to $25.3 \mathrm{Mt} \mathrm{CO}_{2}$ equivalent according to the fuel to be substituted.

Table $5 \mathrm{CH}_{4}$ emission reduction from manure management in Turkey

\begin{tabular}{cccccccc}
\hline $\mathrm{T}$ & $\mathrm{N}$ & $\mathrm{VS} / \mathrm{kg} \cdot(\mathrm{animal} \cdot \mathrm{d})^{-1}$ & $\mathrm{~B}_{\mathrm{o}} / \mathrm{m}^{3} \mathrm{CH}_{4} \cdot \mathrm{kg}^{-1}$ & $\mathrm{MCF} / \%$ & $\mathrm{EF} / \mathrm{kg} \mathrm{CH}_{4} \cdot \mathrm{a}^{-1}$ & $\mathrm{CH}_{4} / \mathrm{kg} \cdot \mathrm{a}^{-1}$ & $\mathrm{CO}_{2-\mathrm{eqv}} / \mathrm{kg} \cdot \mathrm{a}^{-1}$ \\
\hline Dairy Cattle & 8892536 & 2.8 & 0.13 & $71-78$ & $69.43-63.20$ & 598591545 & 14964788620 \\
Laying hens & 97988312 & 0.02 & 0.39 & 1.5 & 0.29 & 2826667 & 64730668 \\
Total & & & & & & 601418212 & 15029519288 \\
\hline
\end{tabular}

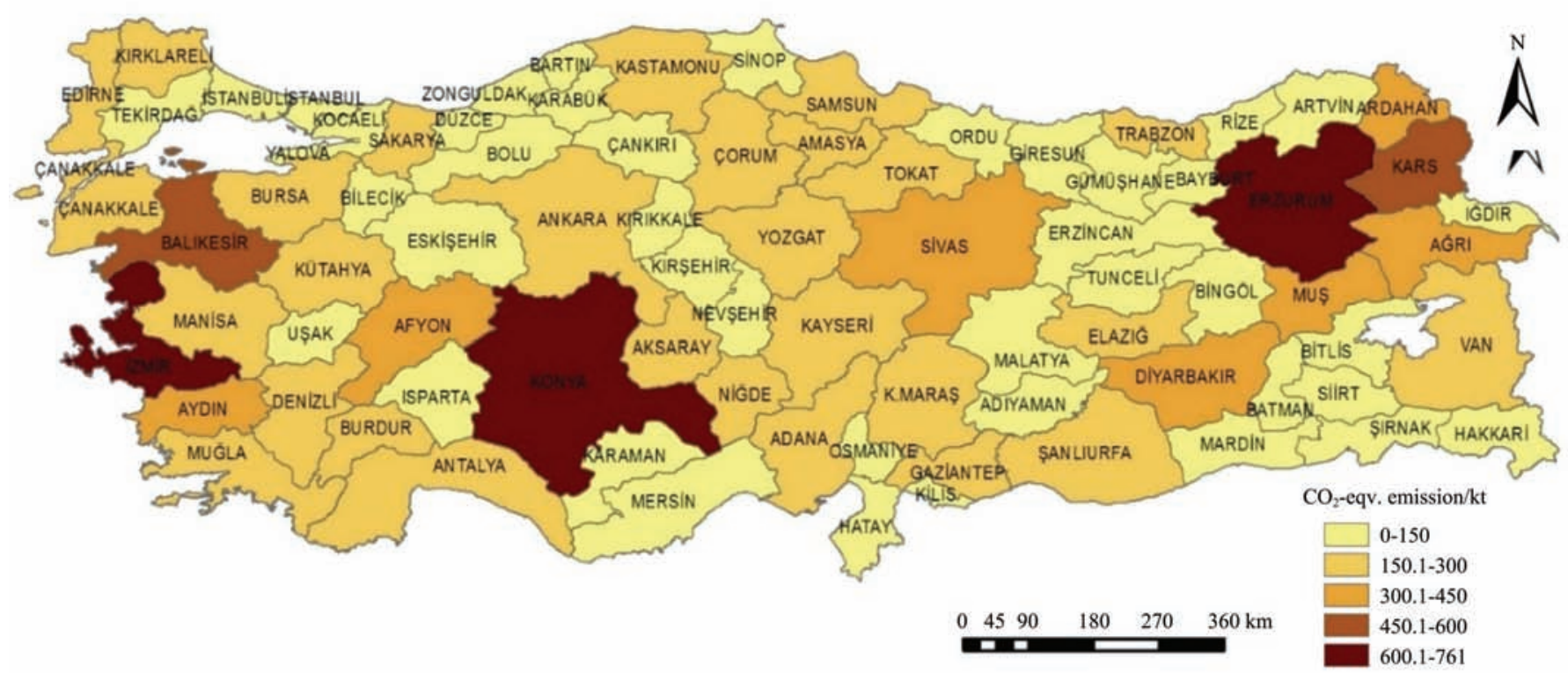

Figure 3 Map of $\mathrm{CO}_{2}$ equivalent emission caused from animal manure by province in Turkey

Table $6 \mathrm{CO}_{2}$ emission reduction from energy substitution in Turkey

\begin{tabular}{ccccc}
\hline Fuels & $\begin{array}{c}\mathrm{FS} \\
/ \mathrm{GJ} \cdot \mathrm{a}^{-1}\end{array}$ & $\begin{array}{c}\mathrm{EF}_{\mathrm{CO} 2 \text { fuel }} \\
/ \mathrm{kg} \cdot \mathrm{GJ}^{-1}\end{array}$ & $\mathrm{CE}_{\text {fuel }}$ & $\begin{array}{c}\mathrm{CO}_{2} \text { emission } \\
/ \mathrm{kg} \cdot \mathrm{a}^{-1}\end{array}$ \\
\hline Firewood & 22015314 & 112 & 0.24 & 10273813297 \\
Coal & 22015314 & 94.6 & 0.40 & 5206621810 \\
Biogas & 22015314 & 0 & 0.60 & 0 \\
Natural gas & 22015314 & 56.1 & 0.57 & 2166770398 \\
\hline
\end{tabular}

Table 7 Total $\mathrm{CO}_{2}$ emission abatement from manure biogas system in Turkey

\begin{tabular}{clcc}
\hline $\begin{array}{c}\text { ERMM } \\
/ \mathrm{t} \cdot \mathrm{a}^{-1}\end{array}$ & \multicolumn{1}{c}{ Fuels } & $\begin{array}{c}\text { ERES }_{\mathrm{CO}_{2} \text { fuel }} / \mathrm{t} \cdot \mathrm{a}^{-1} \\
\text { Firewood }\end{array}$ & $\begin{array}{c}\text { Total } \mathrm{CO}_{2} \text { emission abatement } \\
/ \mathrm{t} \cdot \mathrm{a}^{-1}\end{array}$ \\
\hline \multirow{2}{*}{15029519} & Coal & 5206622 & 25303332 \\
& Natural Gas & 2166770 & 20236141 \\
& & 17196289 \\
\hline
\end{tabular}

\section{Conclusions}

In this study, it was detected that the biogas potential of Turkey from dairy cattle and laying hens manures is $1616.4 \mathrm{Mm}^{3} / \mathrm{a}$ depending on the number of the animals in the years 2015 . The $33.48 \%$ of this potential was enabled by 10 provinces. The most remarkable ones of these provinces are Konya, Izmir, Erzurum, Balikesir, Afyon and Kars.

If all the biogas potential from animal manure is converted into electric energy by means of a gas engine, $4077 \mathrm{GW} \cdot \mathrm{h}_{\mathrm{el}} / \mathrm{a}$ electric energy can be obtained. Although Turkey has a large biogas potential, this potential cannot be adequately assessed. At present in Turkey, there are 19 biogas plants with a total installed capacity of $43.41 \mathrm{MW}_{\mathrm{el}}$. While electricity production potential from biogas in Turkey is $547.53 \mathrm{MW}_{\mathrm{el}}$, today only $8 \%$ of this potential is evaluated.

In this study, the produced maps were provided to see more clearly the differences of data among the provinces. The mapping can enhance public and policy-makers' awareness about these subjects.

The main advantage of biogas systems is to produce renewable energy while equilibrating manure waste. Biogas energy can be a solution to some problems like climate change and high energy costs. Biogas system decreases smell and the hazard of ground-water pollution originating from animal manure. In addition, this technology can increase employment opportunities in rural regions. Using most amount of agricultural waste to produce biogas can present farmers additional income and successfully solve manure-bounded environmental problems. The biogas production from animal manure helps decrease $\mathrm{CO}_{2}$ emissions and protect the environment.

In conclusion, Turkey has great potential in terms of renewable energy sources, but unfortunately, it is an energy-importing country. Turkey needs to use more of its renewable energy sources in order to be independent with regards to energy. Therefore, biogas can be a very glamorous option since it is sustainable, environmentally friendly and a domestic energy resource for Turkey. Alternative energy sources like biogas will likely conclude with more effective endeavors for the energy policy makers. Therefore, Turkey can gain speed to diversify the energy mixture and enhance the share of renewable energy resources in the primary energy production in the future. 


\section{[References]}

[1] Karaca C. Mapping of energy potential through annual crop residues in Turkey. Int J Agric \& Biol Eng, 2015; 8(2): 104-109.

[2] Al Seadi T, Rutz D, Prassl H, Köttner M, Finsterwalder T, Volk S, et al. Biogas handbook. University of Southern Denmark Esbjerg, Denmark, 2008.

[3] Møller H B, Nielsen A M, Murto M, Christensson K, Rintala J, Svensson $\mathrm{M}$, et al. Manure and energy crops for biogas production: Status and barriers, Nordic Council of Ministers, Copenhagen, Denmark, 2008.

[4] Zhu G, Li J, Jha A K. Anaerobic treatment of organic waste for methane production under psychrophilic conditions. Int. J. Agric. Biol., 2014; 16: 1025-1030.

[5] Kulišić B, Par V. Agricultural potential for biogas production in Croatia. Agriculturae Conspectus Scientificus, 2009; 74(3): 215-220

[6] MENR (Ministry of Energy and Natural Resources). Turkey's energy profile and strategy, 2015. Available: www.enerji.gov.tr. Accessed on [2017-4-23]

[7] Akbay C, Boz I. Turkey's livestock sector: Production, consumption and policies. Livestock Research for Rural Development, 2005; 17(9).

[8] TUIK (Turkish Statistical Institute). Livestock statistics: All province of Turkey, 2015.

[9] Başçetinçelik A, Karaca C, Öztürk H H, Kacıra M, Ekinci K. Agricultural biomass potential in Turkey. Proceedings of the 9th International Congress on Mechanization and Energy in Agriculture \& 27th International Conference of CIGR Section IV: The Efficient Use of Electricity and Renewable Energy Sources in Agriculture, İzmir-Turkey, 2005; 195-99.

[10] Başçetinçelik A, Öztürk H H, Karaca C, Kacıra M, Ekinci K, Kaya D, et al. Final Report of Exploitation of Agricultural Residues in Turkey. AGRO-WASTE - Exploitation of Agricultural Residues in Turkey. EU Life Program Project, Project No: LIFE03 TCY/TR/000061. 2006.

[11] Ozsoy G, Alibas I. GIS mapping of biogas potential from animal wastes in Bursa, Turkey. Int J Agric \& Biol Eng, 2015; 8(1):74-83.

[12] Clarke Energy. CHP efficiency for biogas, 2016. Available: ttps://www.clarke-energy.com/2013/chp-cogen-efficiency-biogas/ Accessed on [2016-6-20]

[13] IPCC (Intergovernmental Panel on Climate Change). Guidelines for national greenhouse gas inventories, V4: Agriculture, forestry and other land use, Chapter 10: Emissions from Livestock and Manure Management, 2006

[14] Guo L. Potential of biogas production from livestock manure in China: GHG emission abatement from 'manure-biogas-digestate' system. Department of Energy and Environment, Division of Energy Technology, Chalmers University of Technology Göteborg, Sweden, 2010.

[15] Avcioğlu Onurbaş A, Türker U. Status and potential of biogas energy from animal wastes in Turkey. Renewable and Sustainable Energy Review, 2012; 16(3): 1557-1561.

[16] Danish Ecological Council. Biogas in Denmark - A potential energy source with benefits for the environment. 2012. Available: http://www.ecocouncil.dk/documents/publikationer/1081-120906-biogas-i n-denmark. Accessed on [2017-3-22]

[17] Grzelak P L, Gis W, Żółtowski A. Potential of biogas production in Poland, Germany and Sweden. 2012. Available: http://www.balticbiogasbus.eu/web/Upload/doc/Wakbrzych_3 July 2012/ Grzelak.pdf. Accessed on [2017-3-22].

[18] Colonna N, Pignatelli V, Alfano V. The state of biogas in Italy potential, targets and strategies in the nREAP framework, Trasnational forum on biogas, Varsaw, 2011.

[19] Gadhia P. Biogas scenario in India. 2016. Available: $\mathrm{http} / / / \mathrm{www} . e c l a r e o n . c o m /$ sites/default/files/09 prnsentation pranav excell ent_renewable_-_dusseldorf_-_v2.pdf. Accessed on [2017-3-22]

[20] TUIK (Turkish Statistical Institute). Greenhouse gas emissions inventory in 2014, Bulletin, 2016. Available: www.tuik.gov.tr. Accessed on [2017-3-22] 